\title{
Respiratory allergies: Salicaceae sensitization (Review)
}

\author{
ADRIAN COSTACHE ${ }^{1}$, OVIDIU NICOLAE BERGHI ${ }^{2}$, ROMICA CERGAN $^{3}$, MIHAI DUMITRU $^{3}$, \\ ADRIANA NEAGOS ${ }^{4}$, LILIANA GABRIELA POPA ${ }^{2}$, CALIN GIURCANEANU $^{2}$ and DANIELA VRINCEANU ${ }^{5}$ \\ ${ }^{1}$ Department of Pathology, 'Carol Davila' University of Medicine and Pharmacy, 020021 Bucharest; \\ ${ }^{2}$ Department of Oncologic Dermatology, 'Elias' Emergency University Hospital, 011461 Bucharest; \\ ${ }^{3}$ Department of Anatomy, 'Carol Davila' University of Medicine and Pharmacy, 050474 Bucharest; \\ ${ }^{4}$ ENT Department, 'George Emil Palade’ University of Medicine, Pharmacy, Science and Technology of Târgu-Mureș, \\ 540139 Târgu Mureș; ${ }^{5}$ ENT Department, Bucharest Emergency University Hospital, 010271 Bucharest, Romania
}

Received January 29, 2021; Accepted March 1, 2021

DOI: $10.3892 / \mathrm{etm} .2021 .10041$

\begin{abstract}
Seasonal allergic rhinitis (SAR) is one of the most frequent chronic conditions of the modern world. Pollen carried by the wind from pollinated trees is a major source of SAR. Betulaceae, Oleaceae and Platanus are the most important sources of airway sensitization with regard to tree pollen and, therefore, they are included in the official recommendations of skin prick testing by different official societies. Salicaceae pollen is a moderate source of pollen sensitization. Conversely, large areas are covered with poplars and willows around the world. A number of studies from many countries showed that in some particular situations (large and compacted areas covered by Salicaceae, weather conditions, air pollution, urban ornamental vegetation), poplar and willow pollens may become of local importance in producing SAR. The aim of this review was to present a synthesis of information regarding Salicaceae pollen allergy showing that, if various unfavorable aspects are brought together, a minor problem (Salicaceae sensitization) can became a public health problem.
\end{abstract}

\section{Contents}

1. Introduction

2. Populus family

3. Salix family

4. Conclusions

Correspondence to: Dr Romica Cergan, Department of Anatomy, 'Carol Davila' University of Medicine and Pharmacy, Bd. Eroii Sanitari 8, 050474 Bucharest, Romania

E-mail: r.cergan@gmail.com

Key words: Salicaceae, Salix, Populus, pollen, allergic sensitization

\section{Introduction}

The Salicaceae family initially included Salix and Populus genera, but later more genera were classified into the Salicaceae family, containing over 1,000 species (1). The Salicaceae family is a woody shrub plant family with wide distribution in cold, tropical, and warm temperate regions and sporadic presence in different varied habitats (1). Populus species play important roles in the ecosystem (land management), plant domestication, conservation (phytoremediation), important sources for wood industry (timber, pallets, plywood, matchboxes, chopsticks, wooden shoes), energy (biomass) and fuel (biofuel) $(1,2)$. Genus Populus contains 29-70 species and, based on their morphological characteristics, they have been grouped into the following six sections: Abaso, Turanga, Populus, Leucoides, Aigeiros, and Tacamahaca $(1,3)$. English names applied to different species include poplar, aspen, and cottonwood. Genus Salix contains approximately 450 species, and two main subclades have been identified $(1,4)$. They are primarily found on moist soils in the Northern Hemisphere, with a wide natural distribution from the tropics to the arctic zones and an extensive cultivation around the world (5). Willows are also used in wood industry (boxes, cricket bats, dolls, toys, turnery, tool handles, veneer), agriculture, energy (biomass), environment (constructed wetlands, hedges, phytoremediation, shelterbelt) (6). Pollens from different species of Salix and Populus species were implicated in the respiratory allergic sensitization to wind-transported pollens. The aim of this review is to present the importance of sensitization to Salicaceae pollen in the context of modern respiratory allergies.

\section{Populus family}

The poplar is among the most widely adaptable and distributed tree species in the Northern Hemisphere (latitude 22-70 $\mathrm{N}$ ), including large areas in countries such as the United States, Canada, Russia, China, Italy and France (7). In Romania, the poplar has been for decades the most used ornamental tree along all the important roads between different towns and villages, in order to prevent the snow in winter. Among the 
many species of poplar that grow worldwide, some of them were investigated regarding their role in pollinosis: Populus trichocarpa (7), Populus deltoides (8), Populus tomentosa (9), Populus hybrida (10). Recent studies evaluated the allergenic capacity of Populus pollen. In total, 28 proteins from $P$. deltoides were identified as putative allergens. The expression patterns across various tissues showed that several allergenic genes are highly expressed in Populus pollen with great attention being paid to the profilin allergen family (8). Proteomics analysis was used to characterize the allergens from $P$. tomentosa mature pollen. In total, 27 proteins were identified as putative allergens, such as heat shock protein, enolase, pollen Ole e 1 allergen, thioredoxin and profilins using the Structural Database of Allergenic Proteins (SDAP) tool and Allergen Online (9).

In the following paragraphs, we shall present several studies that evaluated the presence of Populus pollens in the atmosphere in different parts of the world. Generally, in the Northern Hemisphere, pollination period starts at the beginning of March and ends in late April (10). Spain was one the countries where the presence of Populus pollen was frequently studied. In the region of Extremadura, weekly concentrations over 4 years were 40 grains $/ \mathrm{m}^{3}$ for Populus nigra and the percentage of sensitization was $32.3 \%$ (11). Populus pollen showed maximum concentrations between 12.00 p.m and 06:00 p.m in the region of Toledo, with a progressively increased concentration during the study period: 2005-2008 with maximum of 606 grains $/ \mathrm{m}^{3} / \mathrm{h}$ in 2007 (12). In a more recent study from the town of Guadalajara, Populus pollen (P. alba and P. nigra) accounted for $7.8 \%$ of the total pollen count and the elevated pollen levels coincided with both easterly and westerly winds blowing in from areas containing rivers and streams (13). Another study realized by the same principal author, Jesús Rojo, recorded a $7.8 \%$ for Populus pollen in the same region of Guadalajara for the period 2008-2013, with a medium concentration of 100-199 grains $/ \mathrm{m}^{3}$, class 7 (14). Monthly airborne pollen concentrations of Populus pollen were significantly positively correlated with monthly admissions with asthma or dyspnea in spring in the town of Porto, Portugal, another region of the Iberian Peninsula (10).

The Mediterranean region is another part of the globe where the Populus species are widely found. In 2009, in the Osijek-Baranja county of north-eastern Croatia, poplar pollen was found with 3,113 grains $/ \mathrm{m}^{3}$, second after birch pollen (15). Populus pollen was low $(0.84 \%)$ in the air in the area of Zagreb, capital of Croatia, as indicated in a previous study (16). A study conducted in the city of Vinkovci, Northeastern Croatia, found a high pollen concentration (76 grains $/ \mathrm{m}^{3}$ on a peak day) and $2.03 \%$ from all pollens counted (17). A $13.8 \%$ of all pollens counted at different sampling sites in the region of Zagreb, in a study performed in 2003, was ascribed to Populus pollen with a peak concentration in the interval 4.00-8.00 a.m. (18). The pollen of trees from the Populus genus (P. alba, P. nigra, and $P$. canadensis) was investigated together with many other pollens in a 10-year aerobiological study (1994-2003) on the Mediterranean island of Crete, Greece, and it was found that $6.07 \%$ of polysensitized patients were sensitive to them (19). Three studies carried out in Turkey at the beginning of the 2000s studied the populus pollen along with other pollens. Skin prick tests among children with respiratory allergies carried out in the Trakya region of Turkey showed high intensity in the children with allergic rhinitis and living in rural areas (20). Populus pollen represented 3.1\% in 1996 and $6.38 \%$ in 1997 in a study conducted in Kayseri, Turkey from all pollens measured. A $38 \%$ of the patients showed positive reaction to Populus alba pollen and $30 \%$ to Populus tremuloides pollen (21). Allergy to Populus alba pollen in patients with seasonal allergic rhinitis living in the region of Ankara provoked a mild clinical picture, despite high Populus alba pollen counts being measured (22).

Central Europe is a region with many areas covered by poplars. Populus pollen concentration in the atmosphere of Lublin (eastern Poland), along with many other pollens, was measured in 2001-2002. High values of mean 24-h concentrations of pollen grains (of 2 years) (631 grains $/ \mathrm{m}^{3}$ ) for a relative long period of time ( 8 days) were recorded (23). Another study carried out by the same authors in the same town for a long period (2001-2012) concluded that taxa Populus was characterized by a large number of days (11), in which its pollen concentrations exceeded the threshold values (24). A study carried out in Bratislava, Slovakia, measured the correlation between airborne pollen counts and the length of pollen season on the concentration of sIgE antibodies. Populus pollen represented $8.02 \%$ of all pollens measured in 2002 and $7.11 \%$ in 2003. A strong and significant positive correlation between pollen counts and sIgE levels in the two years analyzed was observed (25). The Szeged region is another part of Central Europe where aerobiological studies, were performed. Daily pollen counts (average daily pollen count per cubic meter of air) of different taxa, including Populus, were taken over the period 1997-2007. Populus pollen counted for $9.6 \%$ from all pollens measured, with Populus alba (White Poplar) and Populus canescens (Grey Poplar) being prevalent in the city and characteristic in floodplain forests along the Tisza and Maros Rivers and I-273 Poplar and Populus x euroamericana (Canadian Poplar) frequently planted in urban parklands and public places (26).

Studies regarding the sensitization and concentration of Populus were also realized on other continents. Two studies are from Canada. The sensitization to poplar pollen was $12.1 \%$ in a research performed at a University-based clinic from Edmonton, Canada (27). Populus (aspen, poplar) pollen was small, but significant associated with acute exacerbations of asthma, severe enough to require hospitalization (28). Poplar sensitization was significant in the dry zones of Mexico in a nationwide skin prick test chart review (29). Populus pollen had a maximum weekly daily average of 103 grains $/ \mathrm{m}^{3}$ in the first week of September (1,470 grains/year) in the region of Talca, Chile (30).

\section{Salix family}

The Salix genus consists of willow trees and shrubs, mostly found in the Northern Hemisphere, with the greatest diversity in China, approximately 100 species in North America, through Europe, and in the Andes. Flowering occurs from February through May, depending on the region (for mid-Europe, including Romania, substantial concentrations are observed between February and May). Willows are amphiphilous trees, with both wind and insect vectors playing important roles. 
Willow pollen could become an important factor in pollinosis based on the high quantities caught on different types of samples worldwide (31). There is a strong cross-reactivity between Salix and Populus pollens based on skin testing and $\mathrm{P}-\mathrm{K}$ neutralization and moderate cross-reactivity between Salicaceae and Fagales based on passive hemagglutination and P-K neutralization (31). Rabensteiner et al showed, in an elegant manner, that pollens from different species (including Salix) presented proteolytic activity and degradation of tear fluid and epithelial cells, which may play an important role in the pathogenesis of allergic reactions affecting the ocular surface (32). Using the SDS-PAGE technique, Ribeiro et al revealed distinct bands in allergic patients sera for different tree pollens, including Salix babylonica: A band with a molecular weight of approximately $52 \mathrm{kDa}$ (P. occidentalis, A. negundo, $S$. babylonica, $Q$. robur, B. pendula and P. hybrida); two bands with molecular weights of approximately 35 and $31 \mathrm{kDa}$ ( $P$. occidentalis, A. negundo, S. babylonica and $B$. pendula) and two other bands with molecular weights of approximately 19 and $16 \mathrm{kDa}$ (P.occidentalis, A. negundo and S. babylonica) (10).

The majority of the studies investigating Salix pollen are performed in Asia. Iran is a country in which some of the studies were conducted. The sensitization to willow pollen was among the common allergies in a cohort of 666 patients from the town Ahvaz, Iran (33). Another retrospective cross-sectional study was carried out in the same town, Ahvaz, which evaluated 408 patients with allergic rhinitis and asthma using total and specific IgE and found $28.2 \%$ sensitization to Salix caprea (34). Turkey is a country where many aerobiological and sensitization studies were carried out. Pollen grains of Salix species constituted 3.46\% of the total pollen in the atmosphere of Bitlis with pollen season starting in the first week of April and lasting until the last week of May (35). Salix species pollens represented $2.17 \%$ from all pollens measured in the region of Bilecik, Turkey (36). Salix species pollen was included in the five most frequent arboreal pollen producers in the atmosphere of Eskisehir: Pinaceae (48.13\%), Salix spp. (9.16\%), Cupressaceae (6.21\%), Rosaceae (3.53\%) and Quercus spp. (3.03\%) (37). The salicaceae pollen was considered to be one of 12 allergens able to detect almost all sensitized patients suffering from respiratory symptoms in Lebanon, according to a study that included 2,350 patients from the period 2004-2011 in the region of Beirut (38). The Salix pollen was measured with important concentrations in the atmosphere of two important towns of Georgia, Tbilisi and Kutaisi (39). Eastern Asia is a part of the globe where the willow pollen was also studied. Salix nigra sensitization was evaluated in $0.5 \%$ patients of 419 Taiwanese patients with allergic rhinitis (40). Willow black pollen sensitization (5\% from the total lot of the study) was found in a group of pregnant women form Taiwan (41). The rate of sensitization to willow pollen was $4.07 \%$ in a pediatric population from the region of Incheon, South Korea (42). Pollen of various species of Salix was measured in an aerobiological study carried out in the region of Zagreb, Croatia at the beginning of the 2000s and represented $6.17 \%$ from all pollens counted (16). A trend towards a peak-date and increased quantities of pollen produced was identified for willow pollen in a study that evaluated pollen season trends for the period 1973-2013 carried out in the region of Stockholm,
Sweden (43). Salix (willow) pollen has been considered to have minimal importance as an aeroallergen, with the airborne pollen loads often being low according to a recent study in Great Britain (44). In a pediatric study carried out in the Great Basin desert region (encompassing most of Nevada and a large portion of Utah, with major cities of Las Vegas and Reno, Nevada, and Salt Lake City, Utah), willow pollen was a significant early sensitizer with an important prevalence in children ages 2-3 years, suggesting that the willow's wide presence in the Great Basin area may account for its ability to provoke allergic sensitization response (45). The need to differentiate between local and systemic conditions mimicking allergic reactions is particularly important (46-48). Previous data suggest that tumor genesis and allergic reactions pathways are entangled (49). Notably, the clinical diagnosis may be complicated by associated pathology, such as diabetes and hepatitis C (50). Various medications can trigger violent immune response and accentuate previous chronic pathology $(51,52)$. Allergies of the Salix family require further research of the innate interactions between lymphocytes (53).

\section{Conclusions}

According to the aforementioned authors and the statements of official societies, such as EAACI (European Academy of Allergy and Clinical Immunology), the Salicaceae pollen is considered a minor allergen that was not included in the recommended aeroallergens to be tested as routine in a patient with presumption of allergic rhinitis. However, there are regions around the world where we can find large areas covered by poplars and willows and where the conditions to have sufficient airborne pollens quantities to provoke sensitization to humans can be accomplished. Allergists and otorhinolaryngologists must be aware of local flora when investigating patients with suspicion of allergic rhinitis or asthma.

\section{Acknowledgements}

Professional editing, linguistic and technical assistance performed by Irina Radu, Individual Service Provider, certified translator in Medicine and Pharmacy (certificate credentials: Series E no. 0048).

\section{Funding}

No funding was received.

\section{Availability of data and material}

All data generated or analyzed during this study are included in this published article.

\section{Authors' contributions}

$\mathrm{AC}$ and ONB contributed substantially to the conception and design of the study, the acquisition, analysis, and interpretation of the data, and were involved in the drafting of the manuscript. RC, $\mathrm{MD}$, and $\mathrm{AN}$, contributed substantially to the acquisition, analysis and interpretation of the data and were involved in the drafting of the manuscript. LGP, CG and DV contributed substantially to 
acquisition of the data and were involved in the critical revisions of the manuscript for important intellectual content. All authors agreed to be accountable for all aspects of the work in ensuring that questions related to the accuracy or integrity of any part of the work are appropriately investigated and resolved. All the authors read and approved the final version of the manuscript.

\section{Ethics approval and consent to participate}

Not applicable.

\section{Patient consent for publication}

Not applicable.

\section{Competing interests}

The authors declare that they have no competing interests.

\section{References}

1. Li MM, Wang DY, Zhang L, Kang MH, Lu ZQ, Zhu RB, Mao XX, Xi ZX and Tao M: Intergeneric relationships within the family salicaceae s.l. based on plastid phylogenomics. Int J Mol Sci 20: 3788, 2019.

2. Braatne JH, Hinckly TM and Stettler RF: Influence of soil water on the physiological and morphological components of plant water balance in Populus trichocarpa, Populus deltoides and their F(1) hybrids. Tree Physiol 11: 325-340, 1992.

3. Eckenwalder EJ: Taxonomic signal and noise in multivariate interpopulational relationships in Populus mexicana (Salicaceae). Syst Bot 21: 261-271, 1996.

4. Wu J, Nyman T, Wang DC, Argus GW, Yang YP and Chen JH: Phylogeny of Salix subgenus Salix s.l. (Salicaceae): Delimitation, biogeography, and reticulate evolution. BMC Evol Biol 15: 31, 2015

5. Kuzovkina YA, Weih M, Romero MA, Charles J, Hust S, McIvor I, Karp A, Trybush S, Labrecque M, Teodorescu TI, et al: Salix: Botany and global horticulture. Horticultural reviews. Janick J (ed). Vol 34. John Wiley \& Sons, Inc., Hoboken, NJ pp447-489, 2008.

6. Guidi Nissim W, Palm E, Mancuso S and Azzarello E: Trace element phytoextraction from contaminated soil: A case study under mediterranean climate. Environ Sci Pollut Res Int 25: 9114-9131, 2018.

7. Wei H, Movahedi A, Xu C, Sun W, Wang P, Li D, Yin T and Zhuge Q: Characterization, expression profiling, and functional analysis of PtDef, a defensin-encoding gene from Populus trichocarpa. Front Microbiol 11: 106, 2020.

8. Zhang J, Wu LS, Fan W, Zhang XL, Jia HX, Li Y, Yin YF, $\mathrm{Hu} \mathrm{JJ}$ and $\mathrm{Lu} \mathrm{MZ}$ : Proteomic analysis and candidate allergenic proteins in Populus deltoides CL. '2KEN8' mature pollen. Front Plant Sci 6: 548, 2015.

9. Wang L, Zhang X, Zhang J, Fan W, Lu M and Hu J: Proteomic analysis and identification of possible allergenic proteins in mature pollen of Populus tomentosa. Int J Mol Sci 19: 250, 2018.

10. Ribeiro H, Oliveira M, Ribeiro N, Cruz A, Ferreira A, Machado H, Reis A and Abreu I: Pollen allergenic potential nature of some trees species: A multidisciplinary approach using aerobiological, immunochemical and hospital admissions data. Environ Res 109: 328-333, 2009.

11. Cosmes Martín PM, Moreno Ancillo A, Domínguez Noche C, Gutiérrez Vivas A, Belmonte Soler J and Roure Nolla JM: Sensitization to castanea sativa pollen and pollinosis in northern extremadura (Spain). Allergol Immunopathol (Madr) 33: 145-150, 2005 (In Spanish)

12. Pérez-Badia R, Vaquero $C$, Sardinero $S$, Galán $C$ and García-Mozo H: Intradiurnal variations of allergenic tree pollen in the atmosphere of Toledo (central Spain). Ann Agric Environ Med 17: 269-275, 2010.

13. Rojo J, Rapp A, Lara B, Fernández-González F and Pérez-Badia R: Effect of land uses and wind direction on the contribution of local sources to airborne pollen. Sci Total Environ 538: 672-682, 2015.
14. Rojo J, Rapp A, Lara B, Sabariego S, Fernández-González F and Pérez-Badia R: Characterisation of the airborne pollen spectrum in Guadalajara (central Spain) and estimation of the potential allergy risk. Environ Monit Assess 188: 130, 2016.

15. Sikora M, Valek M, Šušić Z, Santo V and Brdarić D: Tree pollen spectra and pollen allergy risk in the Osijek-Baranja county. Arh Hig Rada Toksikol 64: 115-122, 2013.

16. Peternel R, Culig J, Mitić B, Vukusić I and Sostar Z: Analysis of airborne pollen concentrations in Zagreb, Croatia, 2002. Ann Agric Environ Med 10: 107-112, 2003.

17. Stefanic E, Rasic S, Merdic S and Colakovic K: Annual variation of airborne pollen in the city of Vinkovci, northeastern Croatia. Ann Agric Environ Med 14: 97-101, 2007.

18. Toth I, Peternel R, Srnec L and Vojniković B: Diurnal variation in airborne pollen concentrations of the selected taxa in Zagreb, Croatia. Coll Antropol 35 (Suppl 2): S43-S50, 2011.

19. Gonianakis MI, Baritaki MA, Neonakis IK, Gonianakis IM, Kypriotakis Z, Darivianaki E, Bouros D and Kontou-Filli K: A 10-year aerobiological study (1994-2003) in the mediterranean Island of Crete, Greece: Trees, aerobiologic data, and botanical and clinical correlations. Allergy Asthma Proc 27: 371-377, 2006.

20. Yazicioglu M, Oner N, Celtik C, Okutan O and Pala O: Sensitization to common allergens, especially pollens, among children with respiratory allergy in the Trakya region of Turkey. Asian Pac J Allergy Immunol 22: 183-190, 2004.

21. Ince A, Kart L, Demir R and Ozyurt MS: Allergenic pollen in the atmosphere of Kayseri, Turkey. Asian Pac J Allergy Immunol 22: 123-132, 2004

22. Celik G, Mungan D, Pinar M and Misirligil Z: Poplar pollen-related allergy in Ankara, Turkey: How important for patients living in a city with high pollen load? Allergy Asthma Proc 26: 113-119, 2005.

23. Weryszko-Chmielewska E and Piotrowska K: Airborne pollen calendar of Lublin, Poland. Ann Agric Environ Med 11: 91-97, 2004.

24. Piotrowska-Weryszko K and Weryszko-Chmielewska E: Plant pollen content in the air of Lublin (central-eastern Poland) and risk of pollen allergy. Ann Agric Environ Med 21: 693-696, 2014.

25. Ščevková J, Dušička J, Hrubiško M and Mičieta K: Influence of airborne pollen counts and length of pollen season of selected allergenic plants on the concentration of sIgE antibodies on the population of Bratislava, Slovakia. Ann Agric Environ Med 22: 451-455, 2015.

26. Makra L, Csépe Z, Matyasovszky I, Deák ÁJ, Sümeghy Z and Tusnády G: The effects of the current and past meteorological elements influencing the current pollen concentrations for different taxa. Bot Stud 55: 43, 2014.

27. Ahmed H, Ospina MB, Sideri K and Vliagoftis H: Retrospective analysis of aeroallergen's sensitization patterns in Edmonton, Canada. Allergy Asthma Clin Immunol 15: 6, 2019.

28. Dales RE, Cakmak S, Judek S and Coates F: Tree pollen and hospitalization for asthma in urban Canada. Int Arch Allergy Immunol 146: 241-247, 2008.

29. Larenas-Linnemann DE, Fogelbach GA, Alatorre AM, Cruz AA, Colín DD, Pech JA, Hernández AM, Imperial DA, del Prado ML, Zapién FJ, et al: Patterns of skin prick test positivity in allergic patients: Usefulness of a nationwide SPT chart review. Allergol Immunopathol (Madr) 39: 330-336, 2011.

30. Mardones P, Grau M, Araya J, Córdova A, Pereira I, Peñailillo P, Silva R, Moraga A, Aguilera-Insunza R, Yepes-Nuñez JJ and Palomo I: First annual register of allergenic pollen in Talca, Chile. Allergol Immunopathol (Madr) 41: 233-238, 2013.

31. Weber RW: Allergen of the month-sandbar willow. Ann Allergy Asthma Immunol 114: A21, 2015.

32. Rabensteiner DF, Rabensteiner J, Horwath-Winter J, Lang-Loidolt D, Wedrich A, Heidinger A, Schwantzer G and Schmut O: Extracts of different pollen species and their effect on human tear fluid and an epithelial cell line. Cutan Ocul Toxicol 38: 93-103, 2019.

33. Shahrooei M, Fayezi A, Shokouhi Shoormasti R, Zakavi F, Golpasand Hagh L, Van Eldere J, Bossuyt X and Van Hoeyveld E: Frequency and pattern of IgE-mediated sensitization to aero and food allergens in Ahvaz, province of Khuzestan in southwestern Iran. Iran J Allergy Asthma Immunol 17: 393-397, 2018.

34. Moradi M, Fayezi A, Momeni M, Javanian A, Amini S and Shahrooei M: Specific IgE assay for respiratory allergens in patients with atopy in Ahvaz, Iran. Iran J Immunol 15: 294-301, 2018.

35. Celenk S and Bicakci A: Aerobiological investigation in Bitlis, Turkey. Ann Agric Environ Med 12: 87-93, 2005. 
36. Türe $\mathrm{C}$ and Böcük $\mathrm{H}$ : Analysis of airborne pollen grains in Bilecik, Turkey. Environ Monit Assess 151: 27-35, 2009.

37. Erkara IP, Cingi C, Ayranci U, Gurbuz KM, Pehlivan S and Tokur S: Skin prick test reactivity in allergic rhinitis patients to airborne pollens. Environ Monit Assess 151: 401-412, 2009.

38. Bazarbachi T, Haddad Y, Irani C, Salameh P, Khoury D, Khayat G, Aoun Z, Riachy M, Dabar G and Ibrahim I: Choosing the best panel of aeroallergen prick-tests for patients in Lebanon with rhinitis and asthma: A retrospective study of 2350 patients. Rev Mal Respir 31: 839-848, 2014 (In French).

39. Abramidze T, Gotua M, Chikhelidze N, Cheishvili T and Gamkrelidze A: Plant aeroallergens in two major cities of Georgia-Tbilisi and Kutaisi. Georgian Med News: 75-80, 2017.

40. Liang KL, Su MC, Shiao JY, Wu SH, Li YH and Jiang RS: Role of pollen allergy in Taiwanese patients with allergic rhinitis. J Formos Med Assoc 109: 879-885, 2010.

41. Yeh CC, Wu KG and Wang PH: High prevalence of IgE sensitization against house dust mites in pregnant women. Medicine (Baltimore) 97: e13293, 2018

42. Park SH, Lim DH, Son BK, Kim JH, Song YE, Oh IB, Kim YH, Lee KH, Kim SY and Hong SC: Sensitization rates of airborne pollen and mold in children. Korean J Pediatr 55: 322-329, 2012

43. Lind T, Ekebom A, Alm Kübler K, Östensson P, Bellander T and Lõhmus M: Pollen season trends (1973-2013) in Stockholm area, Sweden. PLoS One 11: e0166887, 2016.

44. McInnes RN, Hemming D, Burgess P, Lyndsay D, Osborne NJ, Skjøth CA, Thomas S and Vardoulakis S: Mapping allergenic pollen vegetation in UK to study environmental exposure and human health. Sci Total Enviro 599-600: 483-499, 2017.

45. Wong V, Wilson NW, Peele K and Hogan MB: Early pollen sensitization in children is dependent upon regional aeroallergen exposure. J Allergy (Cairo) 2012: 583765, 2012.
46. Bumbacea RS, Corcea SL, Ali S, Dinica LC, Fanfaret IS and Boda D: Mite allergy and atopic dermatitis: Is there a clear link? (Review). Exp Ther Med 20: 3554-3560, 2020.

47. Rotaru M, Iancu GM, Gheucă Solovăstru L, Glaja RF, Grosu F, Bold A and Costache A: A rare case of multiple clear cell acanthoma with a relatively rapid development of the lower legs. Rom J Morphol Embryol 55 (Suppl 3): S1171-S1179, 2014.

48. Solomon I, Ilie MA, Draghici C, Voiculescu VM, Căruntu C, Boda D and Zurac S: The impact of lifestyle factors on evolution of atopic dermatitis: An alternative approach. Exp Ther Med 17: 1078-1084, 2019.

49. Georgescu EF, Mogoantă SŞ, Costache A, Pârvănescu V, Totolici BD, Pătraşcu S and Stănescu C: The assessment of matrix metalloproteinase-9 expression and angiogenesis in colorectal cancer. Rom J Morphol Embryol 56: 1137-1144, 2015.

50. Rusu E, Jinga M, Rusu F, Ciurtin C, Georgiana E, Dragomir A, Cristescu V, Stoica V, Costache A, Cheta D and Radulian G: Statin therapy in patients with diabetes and hepatitis C. Farmacia 61: 1204-1215, 2013

51. Vrinceanu D, Dumitru M, Stefan A, Neagos A, Musat G and Nica EA: Severe DRESS syndrome after carbamazepine intake in a case with multiple addictions: A case report. Exp Ther Med 20: 2377-2380, 2020

52. Mihaela Leru P, Florin Anton V, Bocsan C, Muntean A and BodaD: Acquire angioedema induced by angiotensin-converting enzyme inhibitors-experience of a hospital-based allergy center. Exp Ther Med 20: 68-72, 2020.

53. Berghi NO, Dumitru M, Vrinceanu D, Ciuluvica RC Simioniuc-Petrescu A, Caragheorgheopol R, Tucureanu C, Cornateanu RS and Giurcaneanu C: Relationship between chemokines and $\mathrm{T}$ lymphocytes in the context of respiratory allergies (Review). Exp Ther Med 20: 2352-2360, 2020. 